\title{
BRITISH COLONIAL RESEARCH
}

\begin{abstract}
COLONIAL Research 1960-61*, shorter again, - this time by some thirty pages, a reduction of 16 per cent in two years, appears later than ever, although some of the reports included were presented to the Colonial Secretary last July and none later than mid-October. Of the Overseas Research Council there is no mention, and with the explanation that the functions transferred to the Department of Technical Co-operation include those previously performed by the Colonial Office Research Department and its advisory committees and council, it is blandly announced that the present volume will be the last to be published. Besides the brief annual report on colonial research and the section dealing with research matters not eovered by the reports of the specialist advisory bodies, it includes the sixteenth annual reports of the Committee for Colonial Agricultural, Animal Health and Forestry Research and of the Colonial Medical Research Committee/Tropical Medicine Research Board, the seventeenth annual report of the Colonial Social Science Research Council, the fourteenth annual reports of the Colonial Economic Research Committee and of the Colonial Pesticides Research Committee, the annual report on fisheries research of the Colonial Fisheries Advisory Committee and reports from the Tsetse Fly and Trypanosomiasis Committee and from the Director of the Anti-Locust Research Centre.
\end{abstract}

The annual report on Colonial Research notes a decrease in expenditure from Colonial Development and Welfare Funds during the year from $£ 1,483,192$ in $1959-60$ to $£ 1,364,637$, although the Committee for Colonial Agricultural Animal Health and Forestry Research expresses anxiety about the provision of finance for inter-territorial work in East Africa, the East African Agricultural and Fisheries Research Council in particular continuing to feel financial stringency. The 117 new schemes and 56 supplementary schemes made during the year from Colonial Development and Welfare Funds, totalling $£ 2,186,869$, brought the total commitment since 1940 to about $£ 21$ million, about $49 \cdot 6$ per cent of which has been for agricultural, animal health and forestry schemes, 18.3 per cent for medical research, $10 \cdot 2$ per cent for tsetse fly and trypanosomiasis research, $7 \cdot 2$ per cent for social science and economic research, 5 per cent for fisheries research, 2.6 per cent for pesticides research, 1.2 por cent for anti-locust research, and 5.9 per cent for miscellaneous schemes, including building research. About $40 \cdot 6$ per cent of the allocation during the year has been for schemes to benefit the East African territories, 4.5 per cent for the West African group, $2 \cdot 3$ per cent for South-East Asian territories, $23 \cdot 6$ per cent for the West Indian Colonies, British Guiana and British Honduras, 6.6 per cent for the Central African territories (Northern Rhodesia and Nyasaland) and 22.4 per cent for other territories and for schemes of general interest.

* Colonial Research 1960-61; Reports of the Committee for Colonial Agricultural, Animal Health and Forestry Research; Colonial Economic Research Committee; Colonial Fisheries Advisory Committee; Colonial Medical Research Committee/Tropical Medicine Research Board; Colonial Pesticides Research Committee; Colonial Social Science Research Council; Tsetse Fly and Trypanosomiasis Committee; Director, Anti-Locust Research Centre, and Research Matters not covered by the above Reports of the Specialist Advisory Bodies. Pp. 353.
1961.) 188. net.
Four new appointments were made to the Research Branch of the Overseas Civil Service, and with 5 officers retiring and 31 resignations, the total stood in March 1961 at 106 compared with 199 in March 1960 , though the latter figure included officers serving with the West African Research Office who are not now serving under Research Branch terms. Two research fellowships were awarded during the year: one to study some aspects of medical parasitology in Kenya, and the other to undertake a study of the Mombo Forests in Tanganyika, and three research studentships were awarded, two in agriculture and one in medicine. One Research Fellow completed his study of the freshwater algae of Lake Victoria and other lakes in the region, and another continued a plankton survey of the Western Indian Ocean. There are several references to shortage of scientific staff in the other reports: for example, staff shortage retarded the work of the research section of the Sierra Leone Fisheries Research and Development Unit and of the East African Veterinary Research Organization; the East African Trypanosomiasis Research Organization was short of research officers; meteorological research is also handicapped by staff shortages; and improved recruitment to the Directorate of Overseas (Geodetic and Topographical) Surveys was again offset by wastage.

More than a third of the report is occupied by the report from the Committee for Colonial Agricultural, Animal Health and Forestry Research, which includes accounts of the work of the East African Agriculture and Forestry Organization and the East African Veterinary Research Organization, of the Imperial College of Tropical Agriculture, of the West Indies Regional Research Centre, the West African Cocoa Research Institute and the West African Institute for Oil Palm Research, as well as research based in the United Kingdom and that carried out by Colonial Departments of Agriculture, Forestry and Animal Health. Reference may be made to the continued work in East Africa on the stomatal behaviour of the leaves of crops and trees as water shortage becomes more acute, in which this year attention was given to the behaviour of finger millet or wimbi (Eleusine coracana) and bulrush millet (Pennisetum typhoideum) and to a new programme of work with maize aimed at discovering a simple and reliable test for classifying a group of fairly similar maizes according to ability to withstand drought without too severe loss of yield. Other work in East Africa was concerned with sorghum breeding, streak disease of maize, rust disease of beans, the nutrition of indigenous cattle, while further progress was made in research on East Coast fever and allied theileriases, while the West African Institute for Oil Palm Research records advances in pioneer oil-mill processing in general as well as in small-scale processing and in oil bleachability.

Next in length is the last report of the Colonial Medical Committee as such, though it is indicated that the Tropical Medicine Research Board will continue to function under the Department of Technical Co-operation. This, too, includes reference to the work of tne regional organizations and to work undertaken and financed by the medical 
departments of Colonial territories, but by far the greater part of the report reviews the work in progress by subjects. Of the work on helminthiasis, in that on loiasis in the Cameroons, a method has been developed for tosting 'Banocide' as a prophylactic in human volunteers, while work on onchocerciasis has been developed at Kumba in the Cameroons and the onchocerciasis research station at Bolgatanga, Ghana. From the East African Instituto for Modical Research, Muranza, Tanganyika, surveys were made of the incidence of Schistosoma mansoni and S. haematobium in school-children in the Western and Southern Highland Provinces of Tanganyilka, and studies on all natural waters within the Usagara area, near Muranza, over the past twenty months have shown that the transmission of $S$. haematobium is largely from small collections of water, of seasonal duration, in which Bulinus (Physopsis) nasutus productus breod. The East African Institute of Malaria and Vector-borne Diseases reports that the most important vector of human bilharziasis in north-east Tanganyika appears to be Bulinus (Physopsis) globosus, while studies in Nairobi by the Bilharzia Research Unit of the Medical Research Council indicate that monthly injections of antimony dimercapto-succinate suppress egg production in urinary bilharzia. Work on the biology of malaria vectors continued and further studies on the causation of liver necrosis in yellow-fever have been made on the livers of African monkeys inoculated with this virus.

An opidemic of a disease, o'nyong-nyong, caused by a mosquito-borne virus previously unknown in Uganda, where about a million cases, but no deaths directly attributable to tho diseaso, were roported, gave tho East African Virus Research Laboratory, Entebbe, ono of its busiest years. The virus is a member of Group A of the arthropoid-borno viruses and work on identification is steadily progressing. There is clear evidence of persistence and multiplication of the virus in both Anopheles funestus and $A$. gambiae, but not in Aedes aegypti. An important advance reported from the study of the geneties of A. aegypti at the London School of Hygiene and Tropical Modicine is the isolation of a partially sexlinked gene producing a bright red eyo colour, revealing a sex-determining mechanism similar to that in Palex pipiens. Work on nutrition in Colonial territories under the Human Nutrition Unit of the Medical Research Council includes studies of the various forms and manifestations of malnutrition, ospecially of the effects in man and animals of low protein, high earbohydrate diets; of protein requircments and protein values of foods; and of nutritional status in relation to food processing and its effect on the nutritional value of the food.

'Tho two shortest reports are those of the Colonial Economic Research Committee and of the Colonial Social Science Research Council, allocations for which for tho year wero $£ 21,402$ and $£ 50,613$, respectivoly, but to the latter are appended reports of the East African Institute for Social Research and the West Indian Institute of Social and Economic Research, to which furthor grants of $£ 31,434$ and $£ 79,549$, respectively, were made, as well as reports from the Nigerian Instituto of Socinl and Economic Research, University College, Ibadan, and the Rhodes-Livingstone Institute for Social Rescarch. The Rescarch Council vicws with great concern the break between tho United Kingdom and overseas territories likely to ensue in social science research on the attainment of indepondence by colonial territories, and urges that it is of the greatest importance to adopt measures to provide facilitios for United Kingdom roscarch in this field in colonial torritories which become independent and to provide liaison between the United Kingdom and independent territories. For this purpose tho Council suggests that it should be reconstituted as an advisory body on matters relating to social science in this wider context.

The annual report on fishcries research of the Colonial Fisherics Advisory Committee reports briefly on the work of the Sierra Leone Fisheries Research and Development Unit, the East African Freshwater Fishorics Research Organization, Jinja, tho East African Marine Fisheries Research Organization, Zanzibar; the Northern Rhodesian-Nyasaland Joint Fishorics Research Organization (which had an extremely busy year), the Tropical Fish Culture Research Institute, Malacca, and the Fisheries Research Station, Hong Kong, but total expenditure during the year was only $£ 113,456$. Some significant changes are reported by the Colonial Pesticides Research Committee, the Research Unit at Arushe becoming the Tropical Pesticides Research Institute, while the home-based unit at Porton becomes the Tropical Posticides 12esoarch Unit, Porton. Both theso are co-operating with the research programme of the World Health Organization for the evaluation of insecticides. The Agricultural Rescarch Council Unit of Experimental Agronomy, Oxford, has investigated the potentialities of 4-chloro-2-butynyl-N(3chlorophenyl) carbonate as a herbicide for control of Avena fatua, and a Weed Research Organization has been formed from the Unit. Work carried out at tho Long Ashton Research Station, Bristol, on spraying techniques and tho determination of spray residues, and by the Rothamsted Experimontal Station on insecticide pick-up is also reported, while the Tsetse Fly and Trypanosomiasis Committee reports a major advance in the discovery that Glossina palpalis is responsible for the transmission of $T$. rhodesiense sleeping sickness in the Busoga area of Uganda, and this species may be responsible for long-torm persistenco of the disease in Loke coast environments. Much information has also been obtained regarding the sociological factors influencing the transmission of the disease.

The Anti-Locust Research Centre report refers to serious financial and structural problems confronting the International African Migratory Locust Organization in view of the acquisition of independence by soveral territories for which Belgium, France and the United Kingdom were formerly responsible, and it is also necessary to make further plans to ensure maintonance of control of the desert locust in East Africa, including preservation of research work. Meanwhile, representatives of the meteorological services of six centros concerned with tho desert locust have undertaken to add reports of rainfall and temperature at a further 25 stations in potential locust-breeding areas to the monthly CLIMAT simals already received at the Centre.

Of the research matters not covered by the reports of the specialist advisory bodies, Overseas Geological Survoys report an outstanding year, with significant increases in the work of the headquarters divisions for geophysics, mineral resources and photogeology. Specialist assistance continued to be given with goochomical, palacomagnetic and seismic rosearch projects. While the Colonial Board Research Committeo has been disbanded, a new Overseas Road Ilosearch Committoe has been constituted to advise 
the Road Research Board on matters of research connected with problems of roads and road transport overseas and Colonial Research includes some account of work carried out by the Tropical Section of the Road Research Laboratory. There is also a report on the work of the Tropical Products Institute, on surface-active agents derived from sugar, vege- table protein for the relief of malnutrition, the unsaponifiable constituents of banana skin wax, the bleachability of palm oil, constitution of tung oils, the development of new sources of essential oils, physiologically active substances from plants, the biological activity of pyrethrum and the biochemistry and physiology of the pyrethrum plant.

\section{MANAGEMENT AND SCIENTIFIC MANPOWER}

$\mathrm{A}$ T a conference at Princeton University during November 1960, which was sponsored by the National Science Foundation, Prof. F. H. Harbison, director of the Industrial Relations Section of Princeton University, described some of the problems his department are investigating in connexion with research on the utilization of scientific manpower*.

Prof. Harbison explained that, despite the advantages offered by industrial research laboratories and their opportunities compared with research departments in academic institutions, the industrial research centres often suffer from schizophrenia. The goals of the corporation and the goals of the professional scientist are not always the same. The scientist. managers of industrial laboratories have, pressing on them, expectations of the corporation for new processes and products and expectations of their subordinate colleagues for professional advancement. Thus, the laboratory managers must face in two directions and understand and speak two languages. This places on them the complex task of engendering enthusiasm in acting as a transmission belt of communication. The top corporation officials do not know how to treat an organization of individuals with sometimes queer but more often indispensable thought processes. Moreover, they find it difficult to measure the contribution of the laboratory to the profit and loss statement.

The industrial research laboratory is under pressure to produce results from new applications of science, and strives to attain status in the scientific community. It must do this in order to attract high-level manpower. The high-status industrial laboratories invariably are those which can claim to be conducting at least some basic research. The laboratories which engage only in applied research are not rated highly in the community, and cannot expect to attract firstclass scientists.

The Government or quasi-Government laboratory is a relatively new organism in American society. It, too, has many assets. It may devote its energies primarily to basic research, or to research of critical importance. Thus, it escapes, in part, the conflict of goals which so often persists in the industrial research centre. It can also command resources for expensive equipment and adequate supporting technical and clerical personnel.

Yet the scientist in this kind of laboratory is not necessarily a 'happy man'. He lives in the most insecure of scientific environments. In many cases he is a 'transient scientist'-on leave for two or three years from a university or an industrial research centre to work on some important project. He may be free to pursue his basic scientific interests, but only for a limited period of time-perhaps insufficient

* Proceedings of a Conference on Academic and Industrial Basic Research, Princeton University, November 1960. (Sponsored by the National Science Foundation.) Pp. vii +87 . NSF $61-39$. (Washington D.C.: Government Printing Office, 1961.) 55 cents. to complete his programme of research. He may become a permanent member of the organization, but there is always the question of how permanent the Government-financed organization may be. Moreover, as a scientist, he may long to be a generator of future scientific manpower. The Government laboratory, however, is not usually a teaching organization, and it is not a good place for the scientist who wants also to be a professor.

The managers of quasi-Government research organizations, therefore, are under pressure to take on a teaching function if they are to achieve renown as permanent homes for the creative scientist. They, like their other organizational counterparts, must develop a managerial system and outlook appropriate to their particular role. The managers of these institutions, as intermediaries between the scientists and Government officials, are faced with unusually frustrating problems of communication. The U.S.S.R. has probably been most successful in building up this kind of organization.

The university has many advantages as an organization to carry on basic research. It also has its problems and shortcomings. In theory, the academic environment offers the scientist free choice of "pathways of research'. 'The university scientist need not be overtly concerned with the application of scientific knowledge to practical problems, nor does the university hire him and tell him what to discover. In the university, the scientist is under no pressure to become a manager, and, most important, the academic scientist has the twin prerequisites of tenure and professorship - a guarantee of freedom of inquiry and a commission to educate a future generation of scientists.

The university environment, however, is in practice not always what it is claimed to be in theory. First of all, teaching takes time, and the scientist may become particularly annoyed with grading papers, attending committee meetings or typing his own letters. More important, he may spend a great deal of time in the applied field as a consultant to Govern. ment or industry. In consequence, he may have little time left for basic research. Finally, the scientist in the university, as in other organizations, may need whole new laboratories costing millions of dollars and employing hundreds of people. At this point, the scientist cannot be a free agent any longer - he must become a scientific organization man. His work must be scheduled and integrated with the efforts of others. The unfamiliar problems of engineering, construction, and supervision of a large staff of technicians bear down on him. He must become a manager of sorts, and a reluctant one, since in the academic community, the 'manager-type' may not be near the top of the totem pole of status. As is often the case, the university research organization is most likely to fail in management of sub-professiona] 